\title{
Performance of Pigeonpea (Cajanus cajan) Intercropping as Influenced by Row Ratios and Nutri Cereal Crops
}

\author{
Mallikarjun", B. G. Koppalkar, B. K. Desai, M. A. Basavanneppa, \\ K. Narayana Rao and Mahadev Swamy \\ University of Agricultural Sciences, Raichur, Karnataka-584104, India \\ *Corresponding author
}

\begin{tabular}{|l|}
\hline Ke y w o r d s \\
$\begin{array}{l}\text { Row proportions, } \\
\text { intercropping, nutri cereal } \\
\text { crops, pigeonpea } \\
\text { equivalent yield and land } \\
\text { equivalent ratio }\end{array}$ \\
\hline Article Info \\
\hline $\begin{array}{l}\text { Accepted: } \\
\text { 20 May } 2018 \\
\text { Available Online: } \\
\text { 10 June } 2018\end{array}$ \\
\hline
\end{tabular}

\section{A B S T R A C T}

Field experiment was conducted during the rainy season of 2015 and 2016 at UAS, Raichur to evaluate the production potential of pigeonpea (Cajanus cajan (L.) under sole and intercropping with nutri cereal crops under two row proportions of 1:1 and 1:2. Ten treatments consisted of intercropping of pigeonpea with millets (nutri cereals) sorghum, pearl millet and foxtail millet in single and double row proportions and their respective sole stand were evaluated. The pooled mean of yield and yield related attributes of pigeonpea increased when intercropping with foxtail millet in 1:1 row ratio (964 and 1017 $\mathrm{kg} \mathrm{ha}^{-1}$ in 2015 and 2016) was found at par with pigeonpea + sorghum (1:1) (889 and 930 $\left.\mathrm{kg} \mathrm{ha}^{-1}\right)$, pigeonpea + foxtail millet $(1: 2)\left(834\right.$ and $\left.861 \mathrm{~kg} \mathrm{ha}^{-1}\right)$ and pigeonpea + pearl millet (1:1) (788 and $836 \mathrm{~kg} \mathrm{ha}^{-1}$ ), respectively. Intercropping of pigeonpea with either sorghum or foxtail millet irrespective of row proportions recorded significantly higher pigeonpea equivalent yield. However intercropping of pigeonpea + sorghum in both 1:1 and 1:2 row proportions was most remunerative with net returns and B: C ratio of 46,597 Rs ha ${ }^{-1}$ and 2.74 and 44,068 Rs ha ${ }^{-1}$ and 2.63 respectively and ensured higher land equivalent ratio of 1.40 and 1.45 respectively indicating higher biological efficiency of systems. Sole stand of pigeonpea were superior in terms yield and yield attributes and pigeonpea equivalent yield over intercropped treatments.

\section{Introduction}

Pigeonpea [Cajanus cajan (L.) Millsp] is an important food legume of the semi-arid tropics of Asia and Africa. It occupies a prime niche in sustainable farming systems of small and marginal rainfed farmers. It occupies a prominent place in Indian rainfed agriculture. The year 2016 was declared as the international year of pulses by the sixty eighth session of the United Nations General Assembly intending to make people more aware of the nutritional value of pulses, of their contribution to sustainability and more reliable food. Also the year should promote production of pulses worldwide, improve crop rotation and improve trade in pulses. Pigeonpea is an integral component in various agro ecologies of the country, mainly inter cropped with cereals, pulses, oilseeds and millets. It is mainly consumed as dry split dhal throughout the country, besides several other uses of various parts of pigeonpea plant. Enhancing the productivity of the crop 
assumes specific significance in India mainly to combat protein malnutrition as it is the main source of protein to the predominant vegetarian population. The main concept of intercropping is to get increased total productivity per unit area and time, besides equitable and judicious utilization of land resources and farming inputs including labour. One of the main reasons for higher yields in intercropping is that the component crops are able to use growth resources differently and make better overall use of growth resources than grown separately (Willey, 1979). Besides, the growth of pigeonpea is very slow in the early stages, during which time the more rapidly growing short duration millets like foxtail millet, pearl millet and sorghum can be conveniently intercropped to utilize the natural resources most efficiently in the early stages of pigeonpea

\section{Materials and Methods}

Field experiments was conducted during the rainy season of 2015 and 2016 at the University of Agricultural Sciences Farm, Raichur on medium black soil having $\mathrm{pH}$ of 8.18 , organic carbon content of 0.56 and $239.29,34.23$ and $267.12 \mathrm{~kg} / \mathrm{ha}$ of available $\mathrm{N}$, $\mathrm{P}$ and $\mathrm{K}$ respectively. The ten treatments consisted of pigeonpea cv. TS-3R (145-150 days duration) as base crop and three nutricereal crops (intercrops) of sorghum cv. 'CSH-16 (110-115 days), pearl millet cv. ICTP-8203 (70-80 days) and foxtail millet cv. SiA-2644 (90-95 days) taken as sole as well as intercrops in single and double row ratios with pigeonpea and were laid out in randomized complete block design with three replications. For sole crop of pigeonpea, sorghum, pearl millet and foxtail millet the spacing followed was $90 \mathrm{~cm} \times 30 \mathrm{~cm}, 45 \mathrm{~cm} \times 10 \mathrm{~cm}, 45 \mathrm{~cm} \times$ $10 \mathrm{~cm}$ and $30 \times 10 \mathrm{~cm}$, respectively. Pigeonpea was grown at $90 \mathrm{~cm} \times 30 \mathrm{~cm}$ spacing in sole as well as in intercropping system. Between two rows of pigeonpea 1 and
2 rows of nutri cereal crops of sorghum, pearl millet and foxtail millet were provided a common row spacing of $45 \mathrm{~cm}$. Therefore, under pigeonpea + nutri cereal crops intercropping, number of pigeonpea rows/plot of sorghum/pearl millet/foxtail millet was 8 and 10 in $1: 1$ and 1:2 row ratios respectively, but number of pigeonpea rows was 8 in both in sole cropping. The nutrients viz., nitrogen, phosphorus and potassium were applied in the form of urea, single super phosphate and muriate of potash, respectively. In sole pigeonpea full dose of recommended dose of fertilizer (25:50:00 kg N, $\mathrm{P}_{2} \mathrm{O}_{5}$ and $\mathrm{K}_{2} \mathrm{O} \mathrm{ha}{ }^{-1}$, respectively) were applied at the time of sowing. The RDF for Sorghum (50:25:0 kg N, $\mathrm{P}_{2} \mathrm{O}_{5}$ and $\mathrm{K}_{2} \mathrm{O} \mathrm{ha}^{-1}$, respectively), Bajra (50:25:0 $\mathrm{kg} \quad \mathrm{N}, \quad \mathrm{P}_{2} \mathrm{O}_{5}$ and $\mathrm{K}_{2} \mathrm{O} \mathrm{ha}^{-1}$, respectively) and foxtail millet $(30: 15: 15 \mathrm{~kg}$ $\mathrm{N}, \mathrm{P}_{2} \mathrm{O}_{5}$ and $\mathrm{K}_{2} \mathrm{O}$ ha $^{-1}$, respectively) were applied as per the plant population in both single and double row ratio. While intercrops sole and their intercropping system, $25 \mathrm{~kg}$ additional $\mathrm{N}$ was applied 30 days after sowing (DAS). In the intercropping system the fertilizers were applied to the component crops according to the treatment details in both years. The fertilizers were placed in furrows opened at $5 \mathrm{~cm}$ away from the seed line (crop row) and covered with soil. Crops were grown in first week of august and third week of July in both 2015 and 2016 years of experimentation respectively. The total rainfall during the crop period was $677.5 \mathrm{~mm}$ and $835.9 \mathrm{~mm}$ in 2015 and 2016, respectively.

The distribution of rainfall in different months of the growing season i.e. July, August, September, October, November and December were 42, 51.4, 316.6, 65.42 .0 and $2.2 \mathrm{~mm}$ in 2015 and 143.2, 78, 292.5, 39.2, 0.0 and 0.3 $\mathrm{mm}$ in 2016, respectively. Crops were sown late by about two months due to delayed onset of south west monsoon during first year of experiment. Rainfall was not well distributed during the cropping season also and 
consequently crop experienced partial moisture stress during later part of the season ensured lower yield of component crops. During second year of experimentation the distribution of rainfall was uniform throughout the cropping period. Consequently crop did not show any moisture stress during the entire crop growth period and resulted in normal yield of component crops. The results of both the years were more or less similar and hence two years data were pooled and statistically analyzed. Different competition indices were calculated as described by Willy (1979). Pigeonpea equivalent yield (PEY) was worked out by converting the yields of intercrops to the yield of pigeonpea on the basis of prevailing market price of each crop. The economics of different crops and crop combinations were computed on the basis of prevailing market rates of produce and agroinputs. The important observation was recorded at appropriate time and procedure.

\section{Pigeonpea equivalent yield}

The seed yield of green gram, black gram and sesame in each plot was converted into pigeonpea seed equivalent yield on the basis of sale price of green gram, black gram and sesame and pigeonpea seed in $1 / \mathrm{kg}$. It was calculated with the following formula.

PEY $=($ Yield of intercrop $x$ Price of intercrop / Price of pigeonpea) + Yield of pigeonpea

\section{Land equivalent ratio (LER)}

Land equivalent ratio is sum of fraction of the yields of intercrops, relative to their sole crop yields. It is calculated with the following formula.

LER $=$ (Yield of pigeonpea in intercropping system / Yield of sole pigeonpea) + (Yield of intercrops in intercropping system / Yield of sole intercrops)

\section{Results and Discussion}

Sole crops of pigeonpea and nutri-cereals showed significantly higher yield attributes that decreased due to intercropping with different nutri-cereal crops in varied row proportions (Table 1). The significantly higher values of yield attributes of pigeonpea i.e. pods/plant (103.48), seeds/pod (3.57) and test weight (11.74 g) was recorded under sole pigeonpea when compared to intercropping systems. Among intercropping systems, pigeonpea + foxtail millet $(1: 1)$ observed significantly higher number of pods per plant (89.18), seeds per pod (3.36) and test weight $(11.22 \mathrm{~g})$ followed by pigeonpea + sorghum $(1: 1)(86.41,3.36$ and $10.98 \mathrm{~g})$, pigeonpea + foxtail millet $(1: 2)(84.38,3.31$ and $10.87 \mathrm{~g})$ and pigeonpea + pearl millet $(1: 1)(82.27,3.26$ and $10.55 \mathrm{~g}$ ), respectively and were on par with one another. More reduction in yield attributes of pigeonpea was found when it was intercropped with nutri-cereal crops in double row ratios than single row ratios due to intense competition effect of greater population pressure of nutri-cereal crops on lesser population of pigeonpea. Maximum grain and biological yield of pigeonpea and nutri-cereal crops was recorded under sole cropping when compared to intercropping systems (Table 1 and 2). In intercropping systems with 1:2 row proportion seed yield of pigeonpea were significantly reduced due to increased population on intercrops. This is in conformity with findings of Mahto et al., (2007) who reported that intercropping with decreased plant density of finger millet in association with pigeonpea resulted in higher seed yield of pigeonpea. The increase in seed yield of pigeonpea in intercropping system with decreased plant density of nutri-creal crops under 1:1 row ratio may be due to wider spacing of intercrop compared to 1:2 row ratio, facilitating effective sharing of growth resources with nutri-cereal crops to get higher seed yield. 
Table.1 Yield and yield attributes of pigeonpea and nutri-cereal crops as influenced by intercropping systems (pooled data of 2 years)

\begin{tabular}{|l|l|}
\hline \multicolumn{1}{|c|}{ Cropping system } \\
\hline $\mathrm{T}_{1}$-Pigeonpea + sorghum $(1: 1)$ \\
\hline $\mathrm{T}_{2}$-Pigeonpea + pearl millet $(1: 1)$ \\
\hline $\mathrm{T}_{3}$-Pigeonpea + foxtail millet $(1: 1)$ \\
\hline $\mathrm{T}_{4}$-Pigeonpea + sorghum $(1: 2)$ \\
\hline $\mathrm{T}_{5}$-Pigeonpea + pearl millet $(1: 2)$ \\
\hline $\mathrm{T}_{6}$-Pigeonpea + foxtail millet $(1: 2)$ \\
\hline $\mathrm{T}_{7}$-Sole pigeonpea $(90 \mathrm{~cm} \times 30 \mathrm{~cm})$ \\
\hline $\mathrm{T}_{8}$-Sole sorghum $(45 \mathrm{~cm} \times 15 \mathrm{~cm})$ \\
\hline $\mathrm{T}_{9}$-Sole pearl millet $(45 \mathrm{~cm} \times 15 \mathrm{~cm})$ \\
\hline $\mathrm{T}_{10}-$ Sole foxtail millet $(30 \mathrm{~cm} \times 10 \mathrm{~cm})$ \\
\hline S. Em. \pm \\
\hline C.D. $($ P $=0.05)$
\end{tabular}

\begin{tabular}{|c|c|c|c|c|c|c|c|c|c|}
\hline \multicolumn{3}{|c|}{ Pigeonpea } & \multicolumn{3}{|c|}{ Nutri-cereal crops } & \multicolumn{4}{|c|}{ Grain yield } \\
\hline \multirow{2}{*}{$\begin{array}{l}\text { Pods/ } \\
\text { plant }\end{array}$} & \multirow{2}{*}{$\begin{array}{c}\text { Seeds/ } \\
\text { pod }\end{array}$} & \multirow{2}{*}{$\begin{array}{c}100 \text { seed } \\
\text { weight }(\mathrm{g})\end{array}$} & \multirow{2}{*}{$\begin{array}{c}\text { No of } \\
\text { Tillers/ plant }\end{array}$} & \multirow{2}{*}{$\begin{array}{l}\text { Length of } \\
\text { earhead }(\mathrm{cm})\end{array}$} & \multirow{2}{*}{$\begin{array}{l}\text { 1000-grain } \\
\text { weight }(\mathrm{g})\end{array}$} & \multicolumn{2}{|c|}{ Pigeonpea } & \multicolumn{2}{|c|}{ nutri-cereal crops } \\
\hline & & & & & & 2015 & 2016 & 2015 & 2016 \\
\hline 86.41 & 3.36 & 10.98 & 1.95 & 18.89 & 26.89 & 889 & 930 & 987 & 1125 \\
\hline 82.27 & 3.26 & 10.55 & 2.00 & 15.22 & 13.74 & 788 & 836 & 854 & 1002 \\
\hline 89.18 & 3.36 & 11.22 & 2.35 & 15.56 & 2.95 & 964 & 1017 & 619 & 660 \\
\hline 80.74 & 3.24 & 10.70 & 2.10 & 21.61 & 27.11 & 771 & 832 & 1114 & 1373 \\
\hline 78.43 & 3.21 & 10.33 & 2.15 & 15.99 & 13.95 & 717 & 751 & 1066 & 1274 \\
\hline 84.38 & 3.31 & 10.87 & 2.50 & 15.98 & 3.02 & 834 & 861 & 741 & 774 \\
\hline 103.48 & 3.57 & 11.74 & - & - & - & 1302 & 1419 & 0 & 0 \\
\hline - & - & - & 2.45 & 22.22 & 27.22 & - & - & 1380 & 1524 \\
\hline- & - & - & 2.40 & 17.45 & 14.01 & - & - & 1319 & 1405 \\
\hline- & - & - & 2.95 & 17.28 & 3.06 & - & - & 1109 & 1157 \\
\hline 2.57 & 0.20 & 0.56 & - & _- & - & 60 & 57 & - & - \\
\hline
\end{tabular}

Table.2 Biological yield, pigeonpea equivalent yield, land equivalent ratio area time equivalent ratio and economics as influenced by intercropping systems (pooled data of 2 years)

\begin{tabular}{|c|c|c|c|c|c|c|c|c|}
\hline \multirow[t]{2}{*}{ Cropping system } & \multicolumn{2}{|c|}{ Biological yield $\left(\mathrm{kg} \mathrm{ha}^{-1}\right)$} & \multirow[t]{2}{*}{ LER } & \multirow[t]{2}{*}{ ATER } & \multirow{2}{*}{$\begin{array}{c}\text { Pigeonpea } \\
\text { equivalent yield } \\
\left(\mathrm{kg} \mathrm{ha}^{-1}\right)\end{array}$} & \multirow{2}{*}{$\begin{array}{l}\text { Cost of } \\
\text { cultivation } \\
\left(\text { Rs.ha }^{-1}\right)\end{array}$} & \multirow{2}{*}{$\begin{array}{l}\text { Net returns } \\
\left(\text { Rs.ha }^{-1}\right)\end{array}$} & \multirow{2}{*}{$\begin{array}{l}\text { Benefit cost } \\
\text { ratio }\end{array}$} \\
\hline & Pigeonpea & nutri-cereal crops & & & & & & \\
\hline $\mathrm{T}_{1}$-Pigeonpea + sorghum $(1: 1)$ & 4098 & 5435 & 1.40 & 1.23 & 1205 & 26958 & 46597 & 2.74 \\
\hline $\mathrm{T}_{2}$-Pigeonpea + pearl millet (1:1) & 3786 & 2804 & 1.28 & 0.97 & 1020 & 26539 & 34953 & 2.32 \\
\hline $\mathrm{T}_{3}$-Pigeonpea + foxtail millet (1:1) & 4403 & 1635 & 1.30 & 1.07 & 1193 & 27423 & 44068 & 2.61 \\
\hline $\mathrm{T}_{4}$-Pigeonpea + sorghum (1:2) & 3689 & 7100 & 1.45 & 1.25 & 1160 & 27171 & 44257 & 2.63 \\
\hline $\mathrm{T}_{5}$-Pigeonpea + pearl millet $(1: 2)$ & 3341 & 3423 & 1.40 & 1.01 & 998 & 26585 & 33721 & 2.27 \\
\hline $\mathrm{T}_{6}$-Pigeonpea + foxtail millet $(1: 2)$ & 3911 & 2133 & 1.30 & 1.02 & 1087 & 27498 & 37928 & 2.38 \\
\hline $\mathrm{T}_{7}$-Sole pigeonpea $(90 \mathrm{~cm} \times 30 \mathrm{~cm})$ & 5189 & 0 & 1.00 & 1.00 & 1360 & 24417 & 56507 & 3.33 \\
\hline$T_{8}$-Sole sorghum $(45 \mathrm{~cm} \times 15 \mathrm{~cm})$ & 0 & 8560 & 1.00 & 1.00 & 406 & 18272 & 8823 & 1.48 \\
\hline $\mathrm{T}_{9}$-Sole pearl millet $(45 \mathrm{~cm} \times 15 \mathrm{~cm})$ & 0 & 7425 & 1.00 & 1.00 & 433 & 17684 & 3100 & 1.18 \\
\hline $\mathrm{T}_{10}$-Sole foxtail millet $(30 \mathrm{~cm} \times 10 \mathrm{~cm})$ & 0 & 2993 & 1.00 & 1.00 & 360 & 18472 & 3370 & 1.18 \\
\hline S. Em. \pm & 465 & & 0.05 & 0.05 & 55 & & 3398 & 0.13 \\
\hline C.D. $(P=0.05)$ & 145 & & 0.16 & 0.20 & 182 & & 10871 & 0.41 \\
\hline
\end{tabular}


Among nutri-cereal crops, intercropping of foxtail millet produced higher seed and mean biological yield of pigeonpea irrespective of row proportion. This might be due to difference in growth habit and variation in the peak demand of soil moisture and nutrients between the component crops. While, sole cropping of intercrops (nutri-ceral crops) recorded the highest grain and biological yield over their respective intercropping systems in varied row proportions as they get more time to complete their life cycle to facilitating better vegetative growth and mobilization of assimilates to the sink.

The intercropping of pigeonpea with sorghum $(1205 \mathrm{~kg} / \mathrm{ha})$ or pigeonpea + foxtail millet $(1193 \mathrm{~kg} / \mathrm{ha})$ in 1:1 row ratio showed comparable yield to sole pigeonpea in terms of PEY (1360 kg/ha). This may be attributed to slow growing habit and temporal differences between the pigeonpea and nutricereal crops. Difference in growth habit and rooting pattern made both crops suitable for intercropping in alternate rows. Due to higher market price of both pigeonpea and sorghum coupled with higher yield of component crops fetched higher pigeonpea equivalent yield than foxtail millet and pearl millet. Further lower yield of component crops in double row ratios resulted in lower pigeonpea equivalent yield. Intercropping of pigeonpea with nutricereal crops resulted in LER more than 1, indicating its advantage (Table 2). Intercropping of pigeonpea with sorghum in $1: 1$ and $1: 2$ row proportion recorded greater biological efficiency of the system (LER of 1.40 and 1.45, respectively). This yield advantage owing to intercropping might be attributed to balanced competition and better utilization of available resource than sole cropping resulting in higher productivity/unit area. The association of pigeonpea with pearl millet in 1:1 row ratio gave lower LER (1.28), indicating inefficient system. However, the yield advantage to the extent of 28 to 45 per cent was obtained due to intercropping of pigeonpea with sorghum, foxtail millet and pearl millet over their respective sole stand crops (Table 2). This indicated that intercropping system was highly efficient in utilizing growth resource than sole cropping of component crops. Similar results of higher LER were reported in pigeonpea + greengram (1:3) row ratio (Udhaya and Kuzhanthaivel, 2015).

Sole pigeonpea observed maximum net returns $\left(46,597 \mathrm{Rs}^{-\mathrm{ha}^{-1}}\right)$ and benefit cost ratio (3.33) closely followed by pigeonpea + sorghum in 1:1 row ratio (Table 2), mainly owing to higher production and lower cost of cultivation in these systems. This is in conformity with the findings of Tiwari et al., (2016) and Arjun Sharma and Guled (2011). While, minimum net return and benefit cost ratio were obtained with pigeonpea + pearl millet in 1:2 row ratio $(33,721$ and 2.27 , respectively). Similar results were reported by Pawar et al., (2013).

Hence it was concluded that instead of sole cropping of pigeonpea, intercropping of pigeonpea with sorghum in both $(1: 1)$ and (1:2) row ratio or pigeonpea with foxtail millet (1:1) could be viable pigeonpea based cropping systems which resulted in higher economical profitability.

\section{References}

Arjun Sharma and Guled, M. B., 2011, Effect of set-furrow cultivation in pigeonpea + pearlmillet and pigeonpea + sesame intercropping systems in shallow black soil under rainfed conditions. Karnataka J. Agric. Sci., 24(5): 643650.

Mahto, D.K., Ahmad, S., Singh, S. and Srivastava, G. P. 2007. Soil fertility and nutrient uptake in finger millet (Eleusine coracana L.) based 
intercropping systems. Journal of Research (BAU) 19(1): 87-90.

Pawar, S. B., Kohire Patil, V. O. and Pawar, H. D., 2013, Integrated nutrient management in pigonpea based intercropping system. Bioinfolet, 10(1): 345-346.

Tiwari, D. K., Kushwaha, H. S. and Sharma, R. S., 2016, Effect of growth and yield of kodo millet (Paspalum scrobiculatum L.) and pigeonpea (Cajanus cajan L.) under sole and intercropped stands Ecol. Environ. Conser, 22(1): 429-437.

Udhaya, N. D. and Kuzhanthaivel, R. L., 2015, Analysis of light transmission ratio and yield advantages of pigeonpea in relation to intercrop and different plant population. African J. Agric. Res., 10(8): 731-736.

Willey, R. W, 1979. Intercropping, its importance and research needs. Part-1. Competition and yield advantages. Field crops Abstr, 32:1-10.

\section{How to cite this article:}

Mallikarjun, B. G. Koppalkar, B. K. Desai, M. A. Basavanneppa, K. Narayana Rao and Mahadev Swamy. 2018. Performance of Pigeonpea (Cajanus cajan) Intercropping as Influenced by Row Ratios and Nutri Cereal Crops. Int.J.Curr.Microbiol.App.Sci. 7(06): 26532658. doi: https://doi.org/10.20546/ijcmas.2018.706.314 